NASA Technical Memorandum 105231 AIAA - 91-3518

\title{
Trade Studies for Nuclear Space Power Systems
}

John M. Smith, David J. Bents, and Harvey S. Bloomfield

Lewis Research Center

Cleveland, Ohio

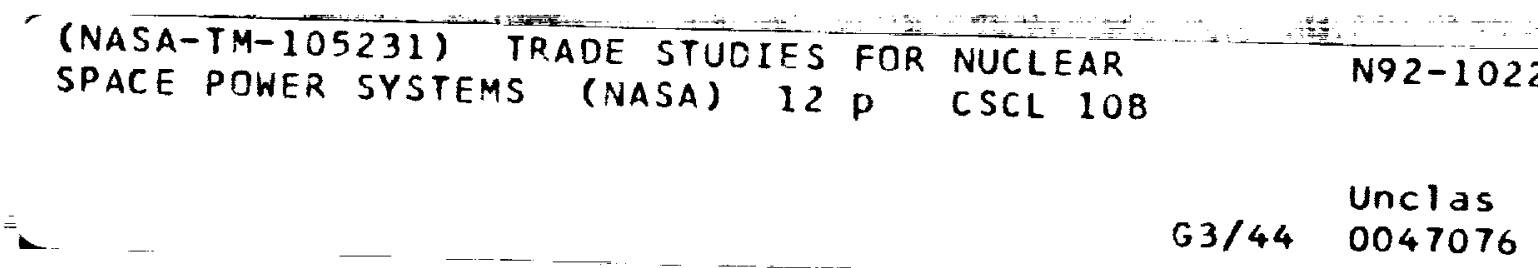

Prepared for the

Conference on Advanced Space Exploration Initiative Technologies cosponsored by AIAA, NASA, and OAI

Cleveland, Ohio, September 4-6, 1991

\section{N/SN}




\section{TRADE STUDIES FOR NUCIEAR SPACE POWER SYSTEMS \\ John M. Smith \\ David J. Bents \\ Harvey S. Bloomfield \\ NASA Lewis Research Center \\ Cleveland, Ohio}

\section{Abstract}

As human visions of space applications expand and as we probe further and further out into the universe, our needs for power will also expand, and missions will evolve which are enabled by nuclear power. A broad spectrum of missions which are enhanced or enabled by nuclear poarer sources have been defined. These include earth orbital platforms, deep space platforms, planetary exploration and extraterrestrial resource exploration. The recently proposed Space Exploration Initiative (SEI) to the Moon and Mars has more clearly defined these missions and their power requirements. This paper presents results of recent studies of radioisotope and nuclear reactor energy sources combined with various energy conversion devices for earth orbital applications, SEI lunar/Mars rover and surface power, and planetary exploration.

\section{Introduction}

In response to President Bush's speech commemorating the 20th anniversary of the Appollo 11 Moon landing. NASA has embarked on a study of returning to the Moon to stay followed by a manned mission to Mars. NASA's initial response to this challenge was to complete a "90 Day Study" (ref. 1) which defined various mission scenarios (architectures) that emphasized different themes and long range goals. These were: science and exploration (emphasis on discovery and acquiring information), aggressive Mars mission (emphasis on getting to Mars with the lunar surface being used primarily as a training station), resource utilization (emphasis on lunar oxygea and helium 3 production) and a final emphasis on permanent lunar/Mars occupancy. To expand this national endeavor to include the best thoughts from within govemment, industry, academia and throughout the country a Synthesis Group was formed which has recently released their findings (ref. 2). While differing in detail and to some extent in emphasis from the " 90 Day Study" there was broad agreement between the studies that space nuclear power was enabling for all the mission architectures that might be considered.

The need for nucleas power becomes evident when one considers the power requirements needed to support transportation, construction and mining vehicles; habitation systems and in-situ resource utilization systems. These power levels range from several kilowatts electric (kWe) to megawatts electric (MWe) and must eventually support the lunar base through the 14 earth-day night and Mars applications through $\& 12$ hour night. The energy storage requirements for these long dark periods make solar energy prohibitively massive and expensive for these high power applications.

Several trade studies investigating the use of radioisotope and nuclear reactor energy sources combined with various energy conversion devices have been performed to address the power requirements of some lunar/Mars applications as well as powes systems for some precursor robotic missions, carth orbital missions and future planetary exploration.

\section{Badioisotope Power Syetems For SEl Applications}

Radioisotope power systems include thermoelectric generators energized by decay heat from a radioisotope beat source and dymamic heat engines energized by the ame heat source. Radioisotope thermoelectric senerators (RTG'S) heve alrendy found broad application for deep space missions as characterized by the Pioneer, Voyager, Galileo ind Ulywes opucecraft. They also provided surface power for the Apollo Lunar Surface Experiments and the Mars Landers. They will find future use in deep rpece with the CRAF and Cassini missions and may well find application on precursor SEI missions which were left undefined in the "90 Day Study". These are low power (less than $1 \mathrm{kWe}$ ) miscions.

The power requirements specified by the " 90 Day Study" indicated that more robust power levels will be required for Lunar/Mars exploration. Power levels which range up to approximately $20 \mathrm{kWe}$ will be more advantageously serviced by dynamic isotope power cystems (DIPS) as shown in fig. 1 where a performance comparison between the presently used General Purpose Heat Source (GPHS) RTG, the anticipated performance of the next generation Mod RTG and a Brayton DIPS is made. Therefore, in the studies to follow the only radioisotope power system considered was the DIPS.

\section{Lunar Rover and Surface Applications}

On the basis of studies carried out during the "90 Day Study" and thereafter, a number of mission enabling or enhancing rover and service vehicles were identified. These were:

Lunar excursion vehicle paylosd unloader (LEVPU): Provides cargo off-loading and emplacement along with site preparation and construction. It is a large teleoperated crane with daytime operation only.

Minine excruatof and repolith hauler. Vehicles used to mine and haul regolith for the in-situ resource utilization (ISRU) plant. Mining only occurs during the lunar day.

Pressurized Rover. Provides a "shirt sleeve" environment for transporting of personnel from the Lunar Excursion Vehicle (LEV) to the habitat, for 4 day exploration missions covering $100 \mathrm{~km}$ or more and as a temporary/emergency habitat. It requires both day and night operation.

Unpressurized Rower: Used for robotic missions of up to 1000 um to perform scientific experiments and for crew transport and site construction during the early phase of base development. Has both day and night operation.

LEV Servicer. Provides power to LEV and auxiliary/emergency power for the lunar base. It operates continuously. 
The operational requirements and characteristics of these devices, as they can be presently defined, sre listed in Table I. From these requirements and a characterization of the vehicle designs required to shieve the above operations, mission power profles were obtained. These profiles fall into three general calegories.

1. Cyclic operation with high peak power requirements, idle periods during the hunar day and little or so lunar night operation. The LEVPU, regolith havler, mining excavator and certain pressurized and unpressurized rover short missions fit this category.

2. Cyctic operations where the active period is increased from the ceveral hours of category 1 to one or more Earth-days, and may include operation during the lunar night. This category is representative of long duration pressurized or unpressurized rover missions.

3. Continuous operation (over one or more lunar day/night periods) with no cyclic or idle operational periods. The LEV senvicer and certain robotic unpressurized rover missions characterize this category.

Representative power profiles for these three categories are shown in Figs. 2-4.

Systems capable of meeting these requirements can be developed now or within the timeframe for the SEI (early 21 st century). They make use of the following technologies:

Solar Photovoltaic (PV)

Hydrogen/Oxygen Primary Fuel Cell (PFC)

Hydrogen/Oxygen Regenerative Fuel Cell (RFC)

Pressurized Gas Reactant Storage for PFC's and RFC's

Cryogenic Reactant Storage

High Energy Density Sodium Sulfur Rechargeable Battery

Dynamic Isotope Power Systems (DIPS)-Brayton Power

Conversion Unit

Two distinct strategies of providing vehicle power can be considered. The first method is the self contained power production system characterized by PV/RFC and DIPS. These systems will be required for long missions away from lunar base and for early missions when the base infrastructure is sparse. The other approach is to periodically refuel or recharge the system with fuel or power produced at the base by means of a solar and/or nuclear power system. In this case the on-board power system would be rechargeable batteries, reactant replenished PFC's, or RFC's.

The candidate power systems were investigated in refs. 3 and 4 for application to the previousty discussed lunar missions. The results shown in figs. 2-4 characterized these applications based on mass, volume and area. The results are discussed below.

For the mission category representative of the regolith hauler, eight different power systems were compared. Three used on-board PV ameys to provide energy to RFC's or NaS batteries. A fourth system used $\mathrm{NaS}$ batteries to provide peaking power with baselond and recharge power provided by a DIPS. Four more aystems utilized lunar base power to recharge NaS batteries, provide refuel for PFC's or to power a RFC electrolyzer. These results are shown in fig. 2. From the power profile it is seen that the peak power greatly exceeds the baseline power level but the energy requirement for the peaks is small due to the short time peaking power is required. Since the vehicle is inactive periodically during the day and not used at all during the lunar night, solar power is an acceptable energy source; however, lunar base refueled PFC's have a considerable mass advantuge while lunar base recharged NaS batteries hove a distinct volume and area advantage which could be a desirable feature for a highly maneuverable vehicle. Similar results were obtained for the LEVPU and mining excavator (ref. 4) and could pertain to certain pressurized and unpressurized rover short missions.

When the cycle period is increased from a few bours to several days, as in the case of the category 2 long range pressurized rover, the energy storage component becomes large enough to make batteries 100 heavy 10 consider. Therefore, fuel cells and DIPS are the only options. For this category RFCs with PV arrays were considered in which case the rover could leave the base for up to 14 Earth-days during the lunar day but normally would be dormant during the lunar night. Altbough the PV/RPC powered rover is recturged and could proceed 4 days into the lunar night it would do 20 only in emergency since it would aot be recharged to begin the next daytight period if it did so. DIPS would hrve a tactical advantage in that it could also be used during the lunar night and does not require recharye periods. The four other rystems using PPC's or RPC's refueled or recharged at lunar base were sized based on returning every 4 days. The results are shown in fig. 3 where it is ceen that the unshielded DIPS has substantial mass advantage over all systems except the recharged PFC using cryo storage. Human-rated shielding for the DIPS can result in a severe mass penalty. The DIPS must scoept either certain operational constraints on manned activity or a penalty for shielding mass. The extent of the penalty is very design oriented, depending strongly on ceparation distance and the use of the vehicle structure for shielding. This is discussed in further detail in ref. 3. The results shown in fig. 3 were based on a shadow shield design at a $2 \mathrm{~m}$ separation distance and an allowable doce of 22 REM over a 90 day mission (22 REM from man-made sources, SO REM overall).

When the power requirement is increased from several days to providing powier continwously through the lunar night, the energy storage component becomes so large that it completely dominates the cystem. The only non-nuclear option which might be considered is a PV/RFC combined with a cryoplant and tankage (ref. 5). More a stationary power plant than a vehicle, this option has at least three times the mass and volume of the DIPS (fig. 4).

From these results, the dynamic isotope power system appears as an option which is competitive for the greatest number of missions and is the only competitive option for continuous power. Because its competitive attributes are more hesvily influenced by application specific factors than the other systems, further examination is warnated. For example, shielding may be required for manned operation but the shielding is specific to the user vebicle configuration and operator schedule. Its impact on the power system gannot be fully assessed until the mission requirements and user installation are better delined.

\section{Comparison of Brayton and Stirline DIPS}

In the previous discussion the DIPS power converion system was a Brayton unit. The continuing development of the high power (10's kWe) free piston Stirling engine (FPSE) as an alternative power converition unit for the SP-100 space nuclear reactor (ref. 6) under the NASA Civil Space Technotogy Initiative High Capacity Power Program (CST//HCP) (ref. 7 and its application use at lower power levels (ref. 8 ) makes it an attrective slternative to the Brayton unit in the DIPS application. In ref. 9 a comparison of these two technologies for the DIPS application was performed. Both the Brayton and Stirling power sysiems used the same DOE General Purpose Heat Source (GPHS). The FPSE chanacterization was based on the CSTI/HCP Space Power Demonstrator Engine (SPDE) and 
small engine designs developed at MTI and the Lewis Research Center. Two heater head temperatures were considered: $1050 \mathrm{~K}$ corresponding to the superalloy engine being constructed under the present phase of CSTI/HCP and $1300 \mathrm{~K}$ corresponding to the refractory engine being designed for the next phase of CSTI/HCP. As shown in fig. 5 three methods of integrating the FPSE with the radioisotope heat source assembly (HSA) were considered. The first cuse uses a liguid metal pumped loop, while the recond employs heat pipes embedded in a carbon/graphite block surrounded by GPHS modules to carry the heat to the FPSE heater head. This recond configuration was studied in greater detail in ref. 10. In the third case the FPSE beater head is surrounded by the GPHS blocks which radiate thermal energy in a directly coupled configuration.

A schematic of the Brayton configuration is shown in fig. 6. The isotope heat cource assembly (HSA) was modeled using an algorithium developed in ref. 11. The Brayton converter (turbomachinery, ducting and heat exchangers) was modeled using the Closed Cycle Engine Performance Code (CCEP) described in ref. 12. Two turbine inlet temperatures (TIT) were considered: 1144K corresponding to superalloy materiais of construction and $1300 \mathrm{~K}$ representative of a refractory metal alloy engine.

Fig. 7 shows the results of a minimum mass optimization analysis of the Brayton and Stirling power systems. The variation in mass of the Stirling power system as a function of output power for the three different FPSE heater head configurations is shown. As would be expected the directly coupled radiative case yields the lowest mass. However, its application is restricted to power levels below $1 \mathrm{kWe}$ where the heater head volume to surface area is favorable. The next best design on a mass basis was the heat pipe coupled configuration. Comparison of the Stirling and Brayton results shows a factor of two decrease in mass for the directly coupled Stirling case as compared to the Brayton in the low power range $(-200 \mathrm{We})$. With scaling to higher power levels $(-20 \mathrm{kWe})$ the advantage is reduced to approximately $20 \%$. The comparison also indicates that the Stirling units require radiator areas approximately half those of the Brayton. Similar results were obtained in ref. 13 where a Stirling power system using a heat pipe coupled heater head was compared to a Brayton system for use as a lunar mobile power source in the range from 2.5 kWe to 15 kWe. That study showed that the Stirling power module was $20 \%$ lower in mass and required $40 \%$ less radiator area than the Brayton system.

\section{Mars Rover/Mars Aircraft}

Although the lunar mission architectures were well defined in the "90 Day Study" and subsequent work, mission profiles and hence power requirements for Mars Missions are not well defined. To date the mission plan closely follows the lunar scenario using basically similar devices. Indeed, one of the main features of the ref. 2 architectures is to use the Moon environs and surface to test and gain operational experience with Mars systems and simulate Mars stay times. However, the martian conditions are very different from those of the Moon, e.g.; 24 hr. versus 28 day day/night cycles, increased gravity, $\mathrm{CO} 2$ atmosphere, dust storms, reduced solar intensity. Therefore, power requirements and system designs require more study.

One uniquely Martian device recently studied at NASA Lewis (ref. 14) is enabled and/or enhanced by the use of nuclear power. The device is a long endurance aircraft operating in the Martian atmosphere to perform such missions as magnetic and gravity field mapping, terrain mapping, atmospheric surveys and surveillance/reconnaissance missions. Since the aircraft is designed to fly continuously for up to a year, an inexhaustible source of energy is required. Two sources were compared: solar PV armas and a radioisotope beat source. The design of the aircreft was based on studies of high altitude aireraft for Earth applications since the atmospheric density encountered at approximately $30.5 \mathrm{~km}$ above Earth is similar to that encountered near the surfece of Mars. A number of Earth applications studies for high altitude airenft were performed in the earty 1980's by NASA Langley Research Center and Lockheed for flight times of up to 1 year. Their concept used solar power with regenerative fuel cells for energy storage.

For the solar powered aircraft "state-of-art" silicon solar cells at $14.2 \%$ efficiency and "far term" thin pllium arsenide solar cells at 25\% efficiency were considered uxing a hydrogen/oxygen regenerative fuel cell for energy etorage. The solar army panels are located over the colar exposed surface of the aircrift. The aireraft is propelled by a propeller attached through a gear box to an electric motor, as shown in fig 8. For a system desiened to operate at $0^{\circ}$ latitude during winter solstice, the aireraft could cover the region from $50^{\circ} \mathrm{S}$ to $50^{\circ} \mathrm{N}$ latitude with a night path that follows the Martian sencons for a period of 1 Martian year. While ref. 14 considered cases allowing higher latitudes the aircraft rapidly increased in size and son became prohibitively large. Therefore, a reasonable sized solar powered aircraft cannot reach to the Martian polar regions.

Two types of radioisotope beat sources were investigated for the Man uircraft: Pu238 (material used in the GPHS RTG) and Cm244 which has more than a 7 fold increase in specific enerzy $(535 \mathrm{vs} 74 \mathrm{~W} / \mathrm{kg})$ over Pu238. Although $\mathrm{Cm} 244$ has been used in the terrestrial applications it has not been qualified for space missions and hence represents "far term" technology. To generate power from the heat source a closed cycle Brayton turboalternator was ueed. The aircraft propeller is driven through a gear box by a turbine and an alternator supplies electrical power for all of the other aircraft functions. A diagram of thit system is shown in fig. 9.

The performance characteristics for the colar and DIPS powered Mars aircraft is presented in Table II. It is seen that for the "state-ofart" systems (14.2\% silicon versus Pu 238 DIPS) and for the "far term" systems(25\% GaAs versus Cm 244 DIPS) the size and mass characteristics of the DIPS powered aireraft are superior to those of the PV powered aircraft. However, both these aireraft due to their ability for controlled night over large amounts of territory are able to perform mission scenarios beyond the capability of satellites, land rovers or balloons. For this capability the DIPS is again the much more desirable system because it can cover the polar regions which are inaccessible to the solar powered aireraft. Therefore, the DIPS is enabling technology for the aircraft surveillance of the Marr polar regions and significantly enhances missions over the rest of the planetary surface. An artist's cooception of the solar powered Mars nircraft is shown in fig. 10.

\section{Space Nurlear Reactor Systems}

When power requirements exceed approximately $20 \mathrm{kWe}$ radioisotope heat sources become far too massive and costly when compared to nuclear reactors. A broad spectrum of missions requiring power at these levels has been defined. These missions include earth orbital platforms; earth science and application experiments; earth orbit, lunar and Mars transport; planetary exploration and extraterrestrial resource exploration. The most widely investigated of these missions have been the earth orbiting platform, lunar/Mars base and planetary exploration. The application of nuclear power to these missions is discussed in this Section. 


\section{Earth Orbitine Phatforms}

When the need for earth orbital power exceeds approximately $50-100$ kWe the use of large solar PV arrays becomes increasingly difficult. Nuclear power oystems have the advantage of simplifying platform dynamics, eliminating the need for continual Sun orientation and, due to their compactness, reduce atmospheric dng in low earth orbit (LEO) with its attendant requirement for propulsive fuel makeup. The compactness of the nuclear system also will facilitate acoess to the platform by other vehicies, the assembly of large space structures such as antennes and increase the viewing area for on-bourd experiments and operations. Potentivl disadvantages are the limitations and constreints imposed by the reactor shielding required to protect platform instrumentation and/or humans.

The application of an SP-100 class nuclear power system to earth orbiting platforms has been atudied (refs. 15-17). The major issues addressed in these studies was that of auclear safety and ndiation profection and assessment of the constraints of reactor shield designs.

In ref. 15, three different methods for coupling the nuclear power cystem to the platform were investigated. These methods were: attaching the reactor directly to the platform, attaching the reactor via a long flexible tether, or locating the reactor on a free-flying power platform. In addition, three options for power transmissions were investigated. These options we re: electrical conduction, fuel transport, or electromagnetic beaming.

The recommended design for the platform mounted reactor was a shadow shielded reactor attached to $70 \mathrm{~m}$ boom with power transmitted by electrical conduction. The design for the tethered reactor occurred for a tether length of $30 \mathrm{~km}$ with power transmission by an electrolycis plant at the reactor. This plant produces and pumps gaseous hydrogen and oxygen through hoses to fuel cells on the main platform. The water produced by the fuel cells is then pumped back to the reactor. This concept proved to be considerably more massive than the boom mounted concept.

In the free flying reactor concept, hydrogen and oxygen are produced on the reactor platform by electrolysis and transported to the main platform by an orbital transfer vehicle which also retums the water produced by fuel cells aboand the main platform. While this concept allows the reactor to reside in a nuclear safe orbit it has the problem of the reactor platform and main platform being in non co-planar orbits for long periods of time due to the difference in drift rates at different altitudes. This results in long storage periods between resupply and/or large propellant consumption from the resulting Delta-V requirements.

In ref. 16 the tethered reactor concept was refined to incorporate electrical power transmission by means of a high voltage DC coaxial tube array, designed to operate in the meteoroid and plasma environment of LEO. Since the tethered reactor has already been chielded to protect its attached machinery, the tether must only be about $2 \mathrm{~km}$ in length to attenuale the renctor radiation from instrument safe levels to buman rated levels. This was potentially the least massive of all the systems studied in refs. 15-17.

While refs. 15 and 16 investigated nuclear power concepts for earth orbiting platforms, ref. 17 studied the critical questions of installation, platform operation and disposal methodology. Human rated shielding configurations were generated for extravehicular activity (EVA), shuttle orbits approach, docking and departure, and EVA for end-oflife separation and disposal of shutdown nuclear reactor power system. A number of disposal destinations including nuclear safe
Earth orbit, colar orbit, colar impact, colar excape, lunar impact and earth return were investigated. Nuclenr we Earth orbit was determined to be the most finorable method of digposal

\section{LunarMars Apolications}

For Earth orbit applieations at power levels up to about a bundred LWe the advantage of nuclear versus solur power is mainly logistical and beace enhancing ruther than eanbling. However, w one looks toward the explortion and commercialization of the Moca and Mars, nuclear power becomes the enabling technology on a mass basis for high capacity continuous power. This is due to the massive energy etorage requirement for colar syotems resulting from the bons luar (14 Earth-days) and Martinn (12 hr) aights.

Athough realized as necesangy for lunar explorntion, the exact ecenario for introduction of auclear reactor power into the architecture depeods highly on the lond profile. A widely considered ccenario (nef. 18) is that the initial outpost power would be supplied by PV/RFC As pomer requirements increase the outpost would add nuclear reactor power, using SP-100 thermoelectric convertion technology (Ref. 6). As power needs expand further to include such demands as In-Situ Resource Utilization (ISRU) plants an SP-100 reactor with highly efficient dynumic convertion would replace thermoelectrics to provide a significant iccrease in power level using the sume reactor technology.

Of primary concem in the use of nuclenr reactors at man-tended sites is humaa radiation protection. In ref. 19 a lunar bese using a $2.5 \mathrm{MW}$ thermal SP-100 nuclear reactor with FPSE power conversion to produce on electrical power output of $825 \mathrm{kWe}$ was considered. As shown in fig. 11, several reactor ndiation shielding options were investigated. The first option was to place the reactor in a crvity either provided by natural terrain, blasting or excrvating. The ndiation shield thus consists of indigenous lunar woil and a Boral bulkhead to prevent soil activation. The second option is a surface mounted reactor and doughnut shaped shield constructed of allemating layers of tungsten and lithium hydride which is transported from Earth. This option is prohibitive on a mass basis since the shield at $20 \mathrm{MT}$ weighs as much as the entire rest of the power system. The third option consisted of mounding wil around the reactor. This requires nearly 20 times the amount of soil to be moved $s$ in the hole excavation concept previously discussed. Since the soil thickness required is approximately $7 \mathrm{~m}$, it also requires long heat transport piping from the reactor to the Stirling power converters. As a result of this study the excavated cervity option was selected.

As a follow on to the above study, ref. 20 compares Stirling. Brayton and thermionics power systems for a lunar buse application (ref. 18). With a common output power $\alpha 550 \mathrm{kWe}$ at 1000 volts DC and a reactor-to-base distance of $250 \mathrm{~m}$ the Stirling cycle configuration used wes that being developed for the NASA CSTI/HCP program and included the 1050K state-of-the-art cuperalloy and $1300 \mathrm{~K}$ advanced refractory metal engines. Two recuperated Brayton cycle concepts were considered: the first operates al a state-of-the-ant turbine inlet temperature (TIT) of 1140K which corresponds to that developed and tested in a previous NASA program (ref. 21), and the tecoond is an advanced design that operates at a TTT of $1300 \mathrm{~K}$ utilizing refractory metals. In all of these cases a SP-100 derived (sized to provide appropriate input power) space nuclear reactor was the heat source.

Two thermionic concepts used for comparison were taken from the five cases analyzed in ref. 22. The first concept utilizes the technology being developed in the Thermionic Fuel Element (TFE) Verification Program (ref. 23). It has a reactor output voltage of \pm 75 volt, a 
conservative interelectrode gap and a $1800 \mathrm{~K}$ emitter temperature. The recond case represents advanced technolozy with a reactor voltage output of \pm 50 volts, a reduced interelectrode gap and an emitter temperature of $2000 \mathrm{~K}$.

Fig. 12 shows a mass comparison for the above cases. Of the "near term" technologies (Baseline TFE, 1140K Brayton and 1050K FPSE) the FPSE system has minimum mass. For the advanced technology cases (Adv. TFE, 1300K Brayton and FPSE) there is very little difference in overall mass. Radiator areas are shown in Fig. 13. It is seen that there is a significant reduction in radiator area for the thermionic cases due to their higher beat rejection temperatures. However, the advantage of a smaller radiator area may not be a system driver on the lunar surface and the effect of high tempenture $(900 \mathrm{~K})$ mdiators on the proximity of other base elements, human presence and maintenance scenarios has not yet been studied.

\section{Solar Syztem Exploration}

Another pontential need for space nuclear reactors is the explontion of the solar system beyond the Moon and Mars. For these missions the distance from the sun is so great that the reduction in solar intensity makes this source marginal and RTG's have been used in past NASA missions. However, with the planning of more ambitious missions and with the ability to maximize mission utilization with increased power the question arises as to the possible advantage of space nuclear reactors to enhance or enable these missions. In an attempt to understand this issue, ref. 24 studied the possible mission benefits of replacing the planned RTG power system on the Mariner Mark II Cassini opacecraft/mission with a small nuclear reactor.

In the first case analyzed a small $1 \mathrm{kWe}$ reactor system was used to simply replace the RTG power system and provide twice the power as shown in fig. 14. In this case the additional mass of the $1 \mathrm{kWe}$ reactor power system located on a $20 \mathrm{~m}$ boom attached to the spacecraft resulted in a light time penalty. The penalty ranged from 0.8 to 1.3 years (depending on the assumed radiation tolerance of the electronios) for the planned 6.8 year mission for the RTG powered spacecraft. Although no major advantage was seen in replacing the present RTG power source with a nuclear reactor for this mission, the elimination of the plutonium isotope and the addition of "power to burn" will make the spacecraft design and operation easier.

In a second case the reactor power was increased so that nuclear electric propulsion (NEP) could be used to replace the chemical propulsion system. In this case a relatively low power 25 to $30 \mathrm{kWe}$ NEP system can deliver the Cassini spacecraft to Satum with no flight time penalty. It also allows a direct trajectory which eliminates all Delta-V gravity assist maneuvers and therefore removes launch window constraints. Moreover, upon reaching Satum the electric propulsion system can be shut down and the reactor power system can be used to dramatically enhance the science portion of the mission.

The attractiveness of small nuclear reactors to provide power for NEP and to enhance/enable mission science is being studied by JPL (ref. 25) and NASA Lewis for several other NASA planetary missions. These missions may include Neptune Orbiter, Pluto Orbiter, Jupiter Grand Tour, Jupiter Polar Orbiter, Multiple Mainbelt Asteroid Rendezvous, Comet Nucleus Sample Return and Uranus Orbiter. The power supply propased for these $100 \mathrm{kWe}$ class missions is the SP-100 thermoelectric system currently under development.. The advantages of using NEP for these missions are: shorter flight times (enabling in some cases); additional science with better performance, accessibility and maneuverability at mission site; and multiple rendezvous.

\section{Concludins Remarts}

Several recent studies have investigated the use of nuclear power for SEI missions and other opace applications. For multi-hundred kWe SEI missions on the Moon and/or Mars nuclear power becomes an enabling technology for many applications due to the long 14 earthdny aight on the Moon and the $12 \mathrm{hr}$ night of Mar. These have prohibitively massive eneroy storage requirements if solar enerdy is used. For power requirements below tens of $\mathrm{kW}$ we redioisotope and colar energy sources can meet ppecific mission requirements. They can be used for robotic precursor missions, lunar/Mars rover and amull mobile/stationary power syatems for baseloed/emergency power for lunar/Mars surface applications. At the power level requirement suggested by the "90 Day Study" dymumic isolope power oystems are found to be advantageous from a mass and cost basis. For these gystems, free piston Stirling enpine power converters show an advantage over Brayton cycles on a mass and radiator area basis.

As space power requirements increase beyond the tens of $k$ We nuge DIPS become too massive and costly and nuclear reactor power becomes enabling. It can be applied to earth orbiting platforms, lunar/Mars surface applications, planetary missions and nuclear electric propulsion. The developing SP-100 space nuclear reactor can acoomplish all of these missions in the ringe of 10-100 kWe when combined with thermoelectric converrion units. Above this power level up to $\sim 1 \mathrm{MWe}$, SP-100 derived reactors with free piston Stirling converts appear to be advantageous. This fulfills the requirements identified by the 90 Day Study". However, NEP for lunar/Mars transport applications requires MWe's of power. For this application - ccaled-up SP-100 derived resctor with Brayton or Rankine conversion is required. For unmanned planetary missions nuclear reactors replacing RTG's provide an advantage in allowing the use of NEP to shorten flight times, eliminate launch windows created by gravity assist maneuvers and provide additional power at mission sites to enhance and/or enable various science missions.

\section{References}

1. Cohen, A., editor: "Report of the 90 Day Study on Human Exploration of the Moon and Mars", NASA Johnson Space Center, November 1989.

2. Stafford, T. P., editor. "America at the Threshold", Synthesis Group Report, U. S. Gov. Printing Off., Washington, DC, May 1991.

3. Bents, D. J., et al, "SEJ Power Source Alternatives for Rovers and Other Multi-kWe Distributed Surface Applications", NASA TM 104359, European Space Power Conference, Barcelona, Spain, September 1991.

4. Withrow, C. A, et al, "SEI Rover Solar-Electrochemical Power Systems Options", NASA TM 104402, May 1991.

5. Kohout, L., "Cryogenic Reactant Storage for Lunar Base Regenerative Fuel Celis", NASA TM-101980, International Conference on Space Power, International Astronautical Federation, Cleveland, Ohio, June 1989.

6. Mondt, J., "Overview of the SP-100 Program", ALAA/NASA/OAI Conference on Advanced SEI Technologies", AlAA Paper No. 91-3585, 1991. 
7. Winter, J. M., The NASA CSTI High Capacity Power Prognm", AlAA Paper No. 91-3629, AlAA/NASA/OAI Conference on Advanced SEI Technologies, September 1991.

8. Ross, B. A, Dudenhoefer, J. E, "Stirling Machine Operating Experience", 26th Intersociety Energy Convertion Engineering Conference, Boston, Mass., Augues, 1991.

9. Bents, D. J. et al, "Comparison of Dynamic Isotope Power Systems for Distributed Planetary Surface Applications", Proceedings of Eighth Symposium on Space Nuclear Power Systems, Vol II, pp. 586-597, Institute for Spece Nuclear Power Studies, Albuquerque, NM, Januiry 1991.

10. Schmitz, P. C., Preliminary Design of a Mobile Lunar Power Supply", NASA TM-104471, June, 1991.

11. Brandewre, R, "Lockheed Missiles and Space Company BSTS Power System Definition Study, Rev. 1", RI/RD86188, Rocketdyne Div., Rockwell International Corporation, Canoga Park, CA., 1986.

12. Klann, J. L. "Status of the 2 to $15 \mathrm{kWe}$ Brayton Power System and Potential Gains from Component Improvements," Intersociety Enerry Conversion Envineerine Conference, 6th Procecdings, Pg. 195-201, Society of Automotive Engineers, 1971

13. Harty, R. B., "A Comparison of Radioisotope Brayton and Stirling Systems for Lunar Surface Mobile Power", Proceedings of Eighth Symposium on Space Nuclear Power Systems, Vol II, pp. 934-937, Institute for Space Nuclear Power Studies, Albuquerque, NM, January 1991

14. Colozza, A. J., "Preliminary Design of a Long-Endurance Mars Aircraft", AlAA Paper No. AIAA-90-2000, July, 1990.

15. Siverman, S. W., Willenberg, H. J. and Robertson, C, "Applicability of $100 \mathrm{kWe}$-Class of Space Reactor Power Systems to NASA Manned Space Station Missions", 018028461-1, Boeing Aerospace Co., NASA CR-174696, 1984.

16. Bents, D. J. , Tethered Nuclear Power for the Space Station", NASA TM 87023, 1985.

17. Bloomfield, H. S. and Heller, J. A., "Feasibility Assessment of Installation, Operation and Disposal Options for Nuclear Reactor Power System Concepts for a NASA Growth Space Station," NASA TM-89923, 1987.

18. Petri, D. A., Cataldo, R. L. and Bozek, J. M., "Power System Requirements and Definition for Lunar and Mars Outposts", Proceeding of the 25th Intersociety Energy Conversion Engineering Conference, Volume I, pp. 18-27, 1990

19. Mason, L S. and Bloomfield, H. S. and Hainley, D. C. "SP-100 Power System Concept Design for Lunar Base Applications", NASA TM 102090 Sixth Symposium on Space Nuclear Power Systems, AJbuquerque, NM, January 1989.

20. Schmitz, P. C. and Mason L. S., "Space Reactor/Stirling Cycle Systems for High Power Lunar Application", NASA
TM 103698, Bighth Symposium on Spece Nuclear Power Syrtems, January 1991.

21. Endish, R E, Pomer Generation From Nuclear Reactors in Aerorpece Applications", NASA TM 83342, November 1982.

22. Mason, L. S., Schmitz, P. C and Gallop, D. R, Tunar lnCore Thermionic Nuclear Reactor Power Syatem Conceptual Design", Proceedinge of the Bighth Symposium on Spece Nuclear Poner Systems", Vol I7, Pp. 651-656, Institute for Space Nuctear Ponver Studies, Abuquerque, NM, January 1991.

23. Bohl, R J, at. Al, Thermionic Fuel Element Verification Propram Overview, Eiphth Symposium on Spece Nuclesr Power Systems, Vol II pp. 636-639, Inctitute for Spece Nuclear Poner Studies Abuquerque, NM, bauary 1991.

24. Bloomfield, H.S, Small Space Reactor Power Syatems for Unmanned Solar System Exploration Miscions", NASA TM 100228, December 1987.

25. Private Communication, Kelly, J. H., Jet Propulsion Laboratory, Pasadena, CA, July 1991. 
TABLE I-MISSION ELEMENTS AND SPECIFIED REQUIREMENTS

\begin{tabular}{|c|c|c|c|c|c|c|c|c|c|}
\hline \multirow[t]{3}{*}{ Mission element } & \multicolumn{9}{|c|}{ Mission } \\
\hline & \multirow[t]{2}{*}{ LEVPU } & \multirow{2}{*}{$\begin{array}{l}\text { Minine } \\
\text { excavator }\end{array}$} & \multirow{2}{*}{$\begin{array}{l}\text { Regolith } \\
\text { hauler }\end{array}$} & \multicolumn{2}{|c|}{ Pressurized rover } & \multicolumn{3}{|c|}{ Unpressurized rover } & \multirow{2}{*}{$\begin{array}{l}\text { LEV } \\
\text { servicer }\end{array}$} \\
\hline & & & & $\begin{array}{l}\text { Shon } \\
\text { nnge }\end{array}$ & $\begin{array}{l}\text { Long } \\
\text { ringe }\end{array}$ & $\begin{array}{l}\text { Seientific } \\
\text { celerobotic }\end{array}$ & $\begin{array}{c}\text { Man } \\
\text { transpor }\end{array}$ & $\begin{array}{c}\text { Recharge and } \\
\text { emergency } \\
\text { power }\end{array}$ & \\
\hline Crew size: & & & & & & & & & \\
\hline Maximum & 1 & 1 & 1 & 4 & 4 & 4 & 4 & 4 & 0 \\
\hline Minimum & 0 & 0 & 0 & 2 & 2 & $\mathbf{0}$ & 0 & 0 & 0 \\
\hline \multicolumn{10}{|l|}{ Capability: } \\
\hline $\begin{array}{l}\text { Paylosd lifting and hauling capacity, } k_{\text {g }} \\
\text { Average velocity, } \mathrm{m} / \mathrm{s}\end{array}$ & $\begin{array}{r}10000 \\
1\end{array}$ & $\begin{array}{r}750 \\
2\end{array}$ & $\begin{array}{r}750 \\
2\end{array}$ & $\begin{array}{l}(2) \\
2.8\end{array}$ & $\begin{array}{l}(a) \\
2.8\end{array}$ & $\begin{array}{r}1200 \\
2.8\end{array}$ & $\begin{array}{r}1200 \\
2.8\end{array}$ & $\begin{array}{r}1200 \\
2.8\end{array}$ & (a) \\
\hline Maximum slope, deg & 6 & 6 & 6 & 20 & 20 & 20 & 20 & 20 & (a) \\
\hline LEV paylond mass allocation, $\mathrm{kg}$ & $15 \infty 00$ & 1000 & 1000 & 4500 & 6000 & 600 & 600 & 600 & (a) \\
\hline \multicolumn{10}{|l|}{ Power requiremens, kWe: } \\
\hline Peak & 10 & 40 & 15 & (a) & (a) & 3 & 0.7 & 5 & 10 \\
\hline Nominal & 3 & 22 & 3 & 7 & 12 & 2 & 0.3 & 5 & 10 \\
\hline Sundby & 3 & 10 & 1.5 & 3 & (a) & (a) & (a) & 5 & 10 \\
\hline \multicolumn{10}{|l|}{ Operation paramelers per cycle, hr al- } \\
\hline Peak power & 1 & 1 & 1 & (2) & (a) & 16 & 336 & (a) & 8560 \\
\hline Nominal power & 11 & 8.6 & 8 & 10 & 96 & 24 & 336 & 960 & 8560 \\
\hline Sundby & 0 & 1.4 & 1.4 & 0 & (a) & 0 & (a) & 0 & 8560 \\
\hline Iracive & 12 & 13.6 & 13.6 & 14 & 48 & 0 & (a) & 0 & 0 \\
\hline
\end{tabular}

No specification.

Table II.

Pertormance Characterlstics for Solar and DIPS Powered

Mars Aircraft

\begin{tabular}{|l|r|r|r|r|}
\hline \multirow{2}{*}{} & \multicolumn{2}{|c|}{ Solar Cell Eff., \% } & \multicolumn{2}{c|}{ Radiolsotope } \\
\cline { 2 - 5 } & \multicolumn{1}{|c|}{14.2} & \multicolumn{2}{c|}{ Pu 238 } & Cm 244 \\
\hline Wing Area, M & $\cdot$ & & & \\
Wing Span, M & 336.00 & 118.72 & 145.00 & 103.00 \\
& 108.00 & 47.50 & 48.20 & 37.97 \\
Airframe, kg & & & & \\
Propulsion, kg & 384.53 & 161.64 & 213.70 & 161.87 \\
Solar Cells, kg & 26.84 & 16.87 & 65.90 & 46.82 \\
Fuel Cell, kg & 159.60 & 56.41 & & \\
Isotope, kg & 151.18 & 94.07 & & \\
Payload, kg & & & 140.80 & 13.76 \\
& 100.00 & 100.00 & 100.00 & 100.00 \\
& & & & \\
Total, kg & & & & \\
& 1189.44 & 438.20 & 521.95 & 307.97 \\
& & & & \\
& & & & \\
\hline
\end{tabular}




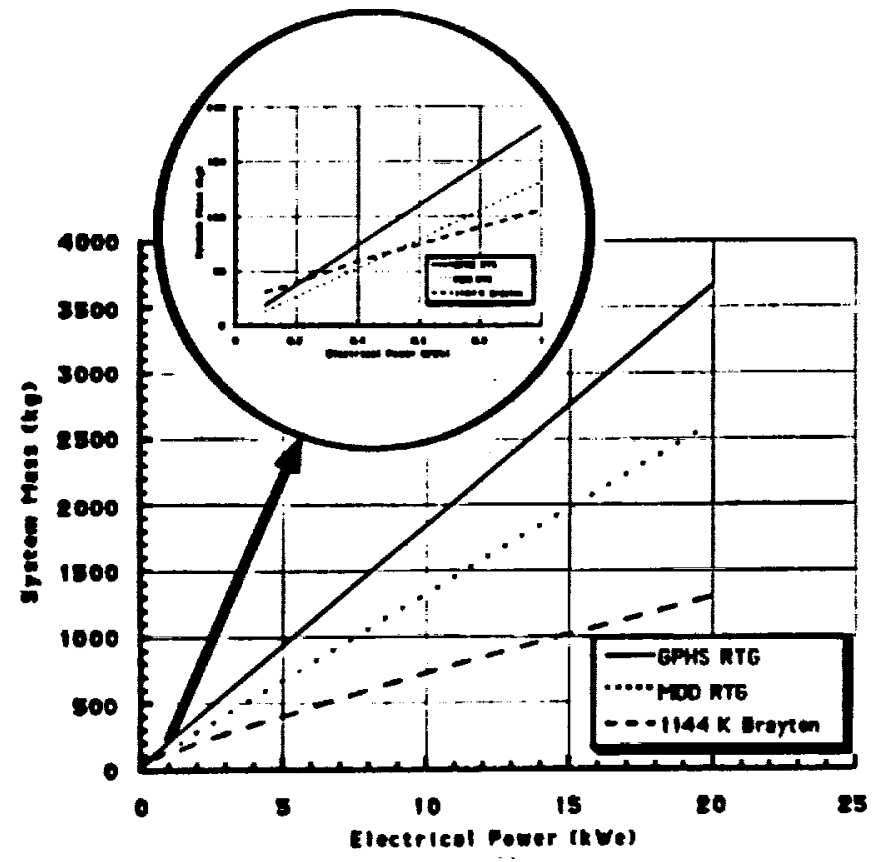

Figure 1. Comparison RTG and DIPS
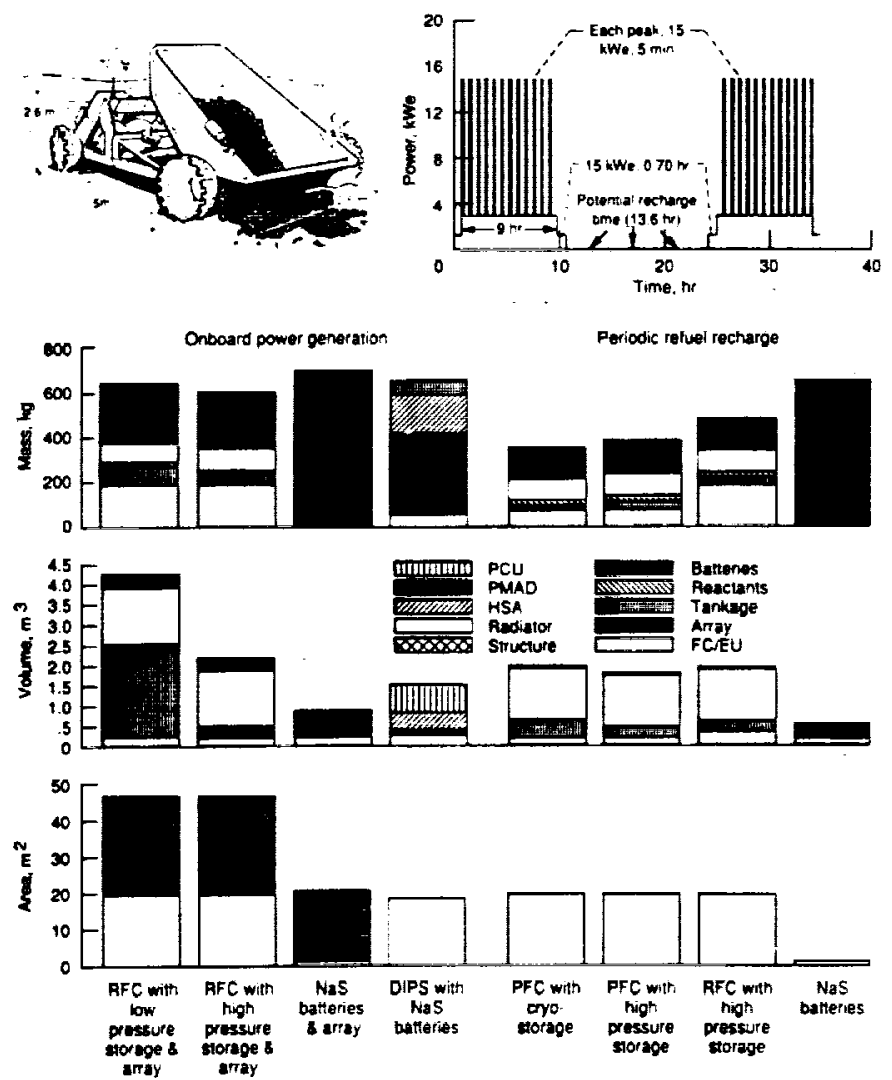

Figure 2. Regolith Hauler
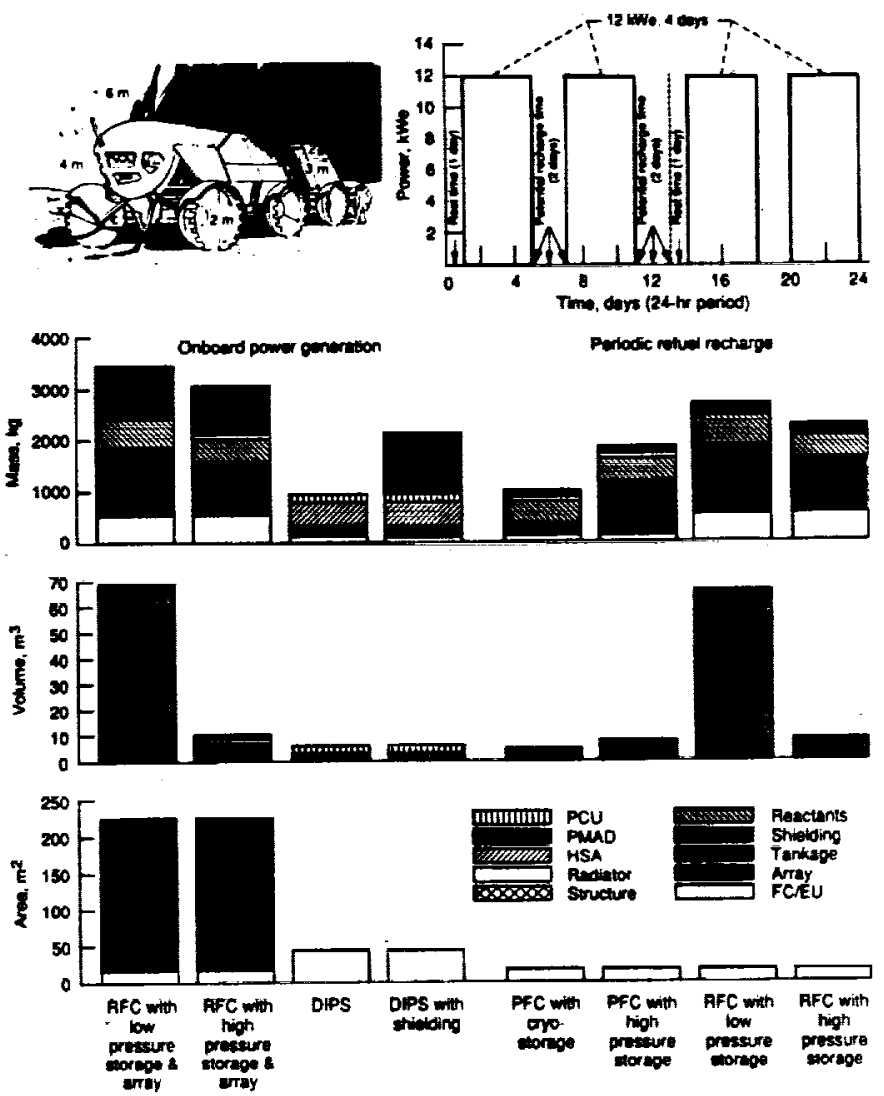

Figure 3. Pressurized Long Range Rover
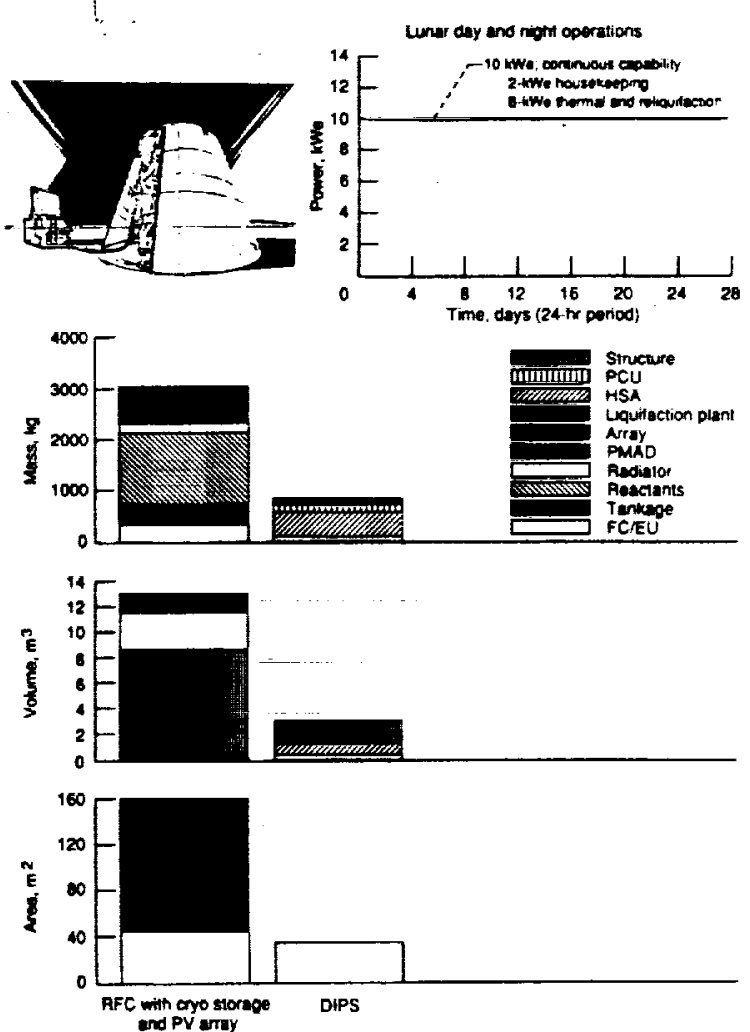

Figure 4. LEV Servicer 


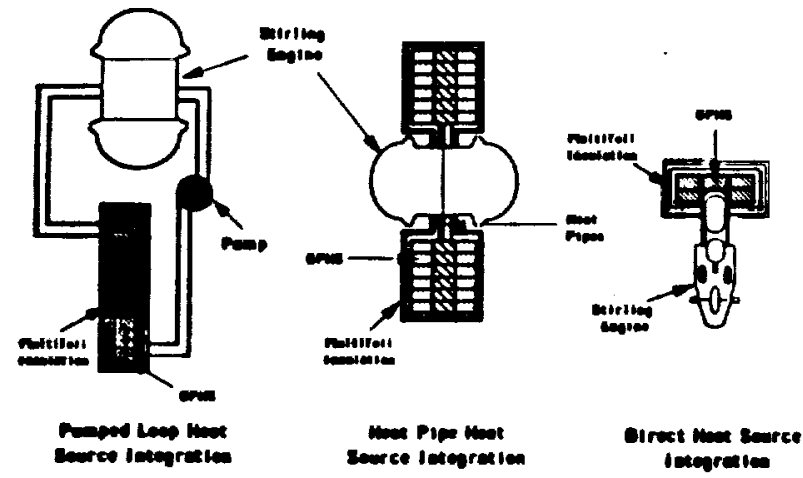

Figure 5. Free Piston Stirling DIPS
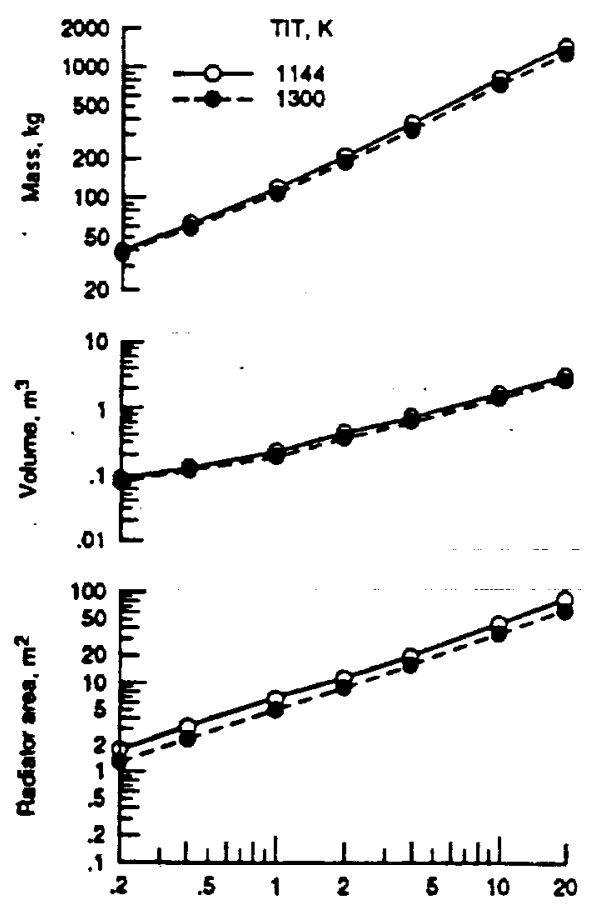

Luner Brayon DIPS

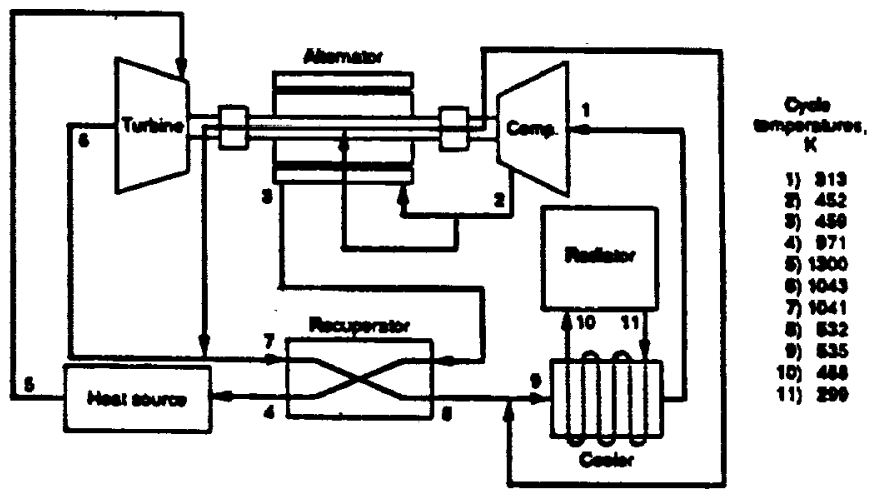

Figure 6. Brayton DIPS Schematic

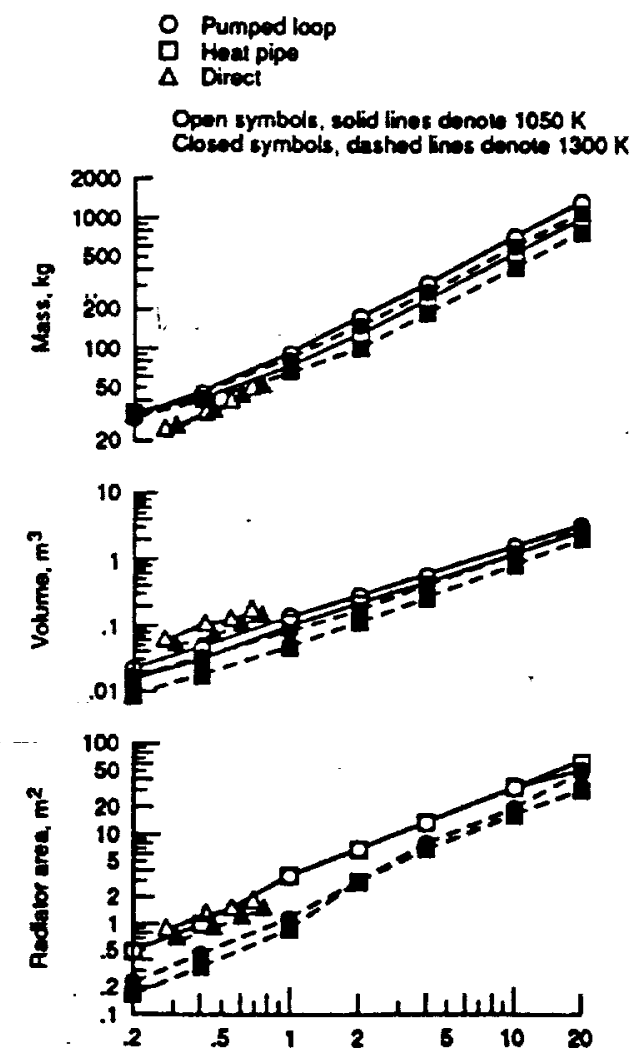

Oubut power, kWe

Unar FPSE DIPS

Figure 7. 


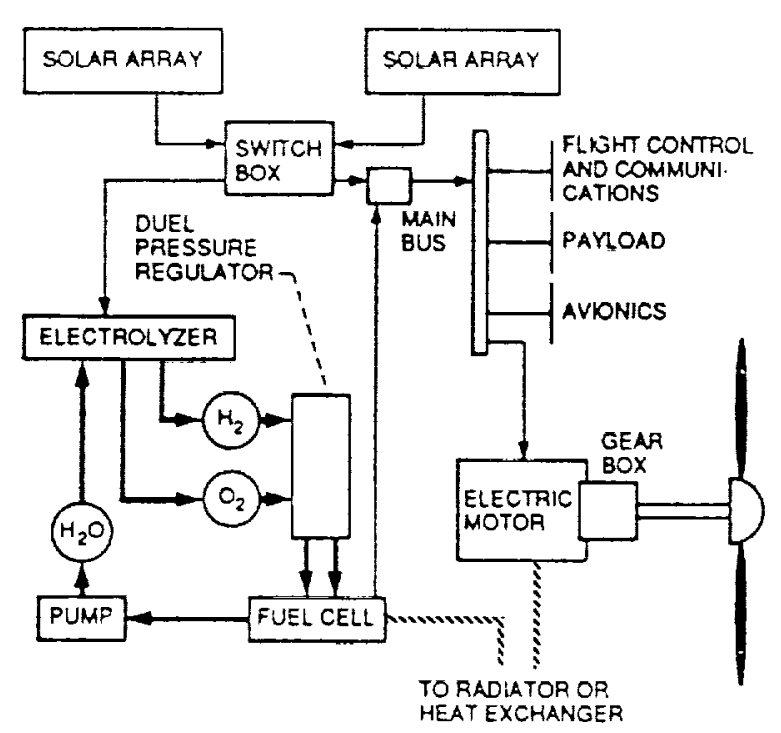

Figure 8. Solar Powered Aircraft Power and Propulsion System Diagram

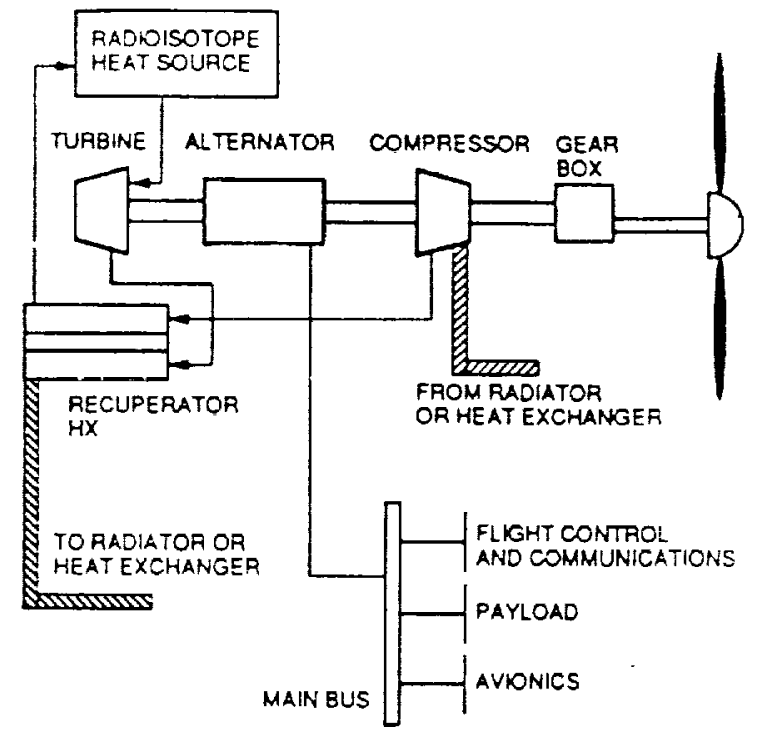

Figure 9. Radioisotope Powered Aircraft Power and Propulsion System Diagram

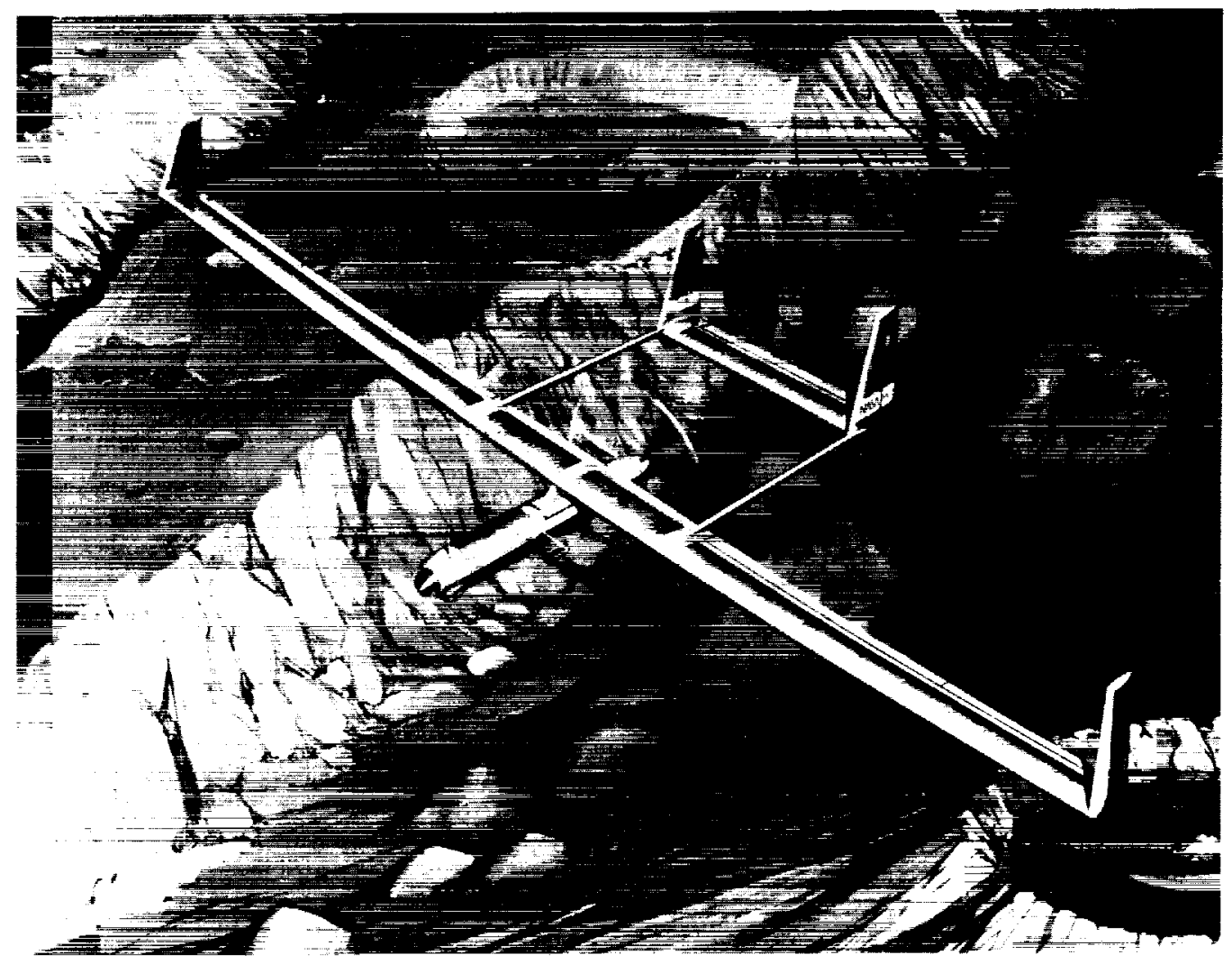

Figure 10. Artist's Conception of Solar Powered Mars Aircraft 


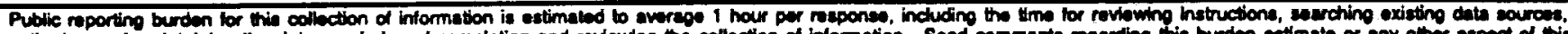

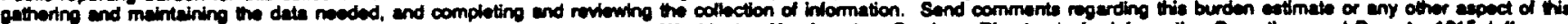
chation

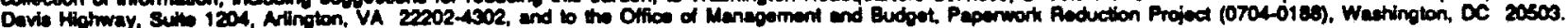
1. AGENCY USE ONLY (Loeve blank)
2. REPOAT DATE
3. REPORT TYPE AND DATES COVERED
Technical Memorandum

\section{TILE AND SUBTIRE}

5. FUNDINO NUMBERS

Trade Studies for Nuclear Space Power Systems

6. AUTHOA(B)

WU-590-13

John M. Smith, David J. Bents, and Harvey S. Bloomfield

\section{PERFORMINO ORGANIZATION NAME(S) AND ADORESS(ES)}

National Aeronautics and Space Administration Lewis Research Center Cleveland, Ohio 44135-3191
- PEAformina organization REPORT NUMBER

$E-6554$

10. SPONSORINO/MONITOAING AGENCY REPORT NUMBER

NASA TM-105231

AIAA - $91-3518$

Washington, D.C. 20546-0001

\section{SUPPLEMENTARY NOTES}

Prepared for the Conference on Advanced Space Exploration Initiative Technologies cosponsored by AIAA, NASA, and OAI, Cleveland, Ohio, September 4-6, 1991. Responsible person, John M. Smith, (216) 433-6130.

12.. DISTRIBUTIONYAVAILABILTY STATEMENT

12b. DISTRIBUTION COOE

Unclassified - Unlimited

Subject Category 44

\section{ABSTAACT (Meximum 200 words)}

As human visions of space applications expand and as we probe further and further out into the universe, our needs for power will also expand, and missions will evolve which are enabled by nuclear power. A broad spectrum of missions which are enhanced or enabled by nuclear power sources have been defined. These include earth orbital platforms, deep space platforms, planetary exploration and extraterrestrial resource exploration. The recently proposed Space Exploration Initiative (SEI) to the Moon and Mars has more clearly defined these missions and their power requirements. This paper presents results of recent studies of radioisotope and nuclear reactor energy sources combined with various energy conversion devices for earth orbital applications, SEI lunar/Mars rover and surface power, and planetary exploration.

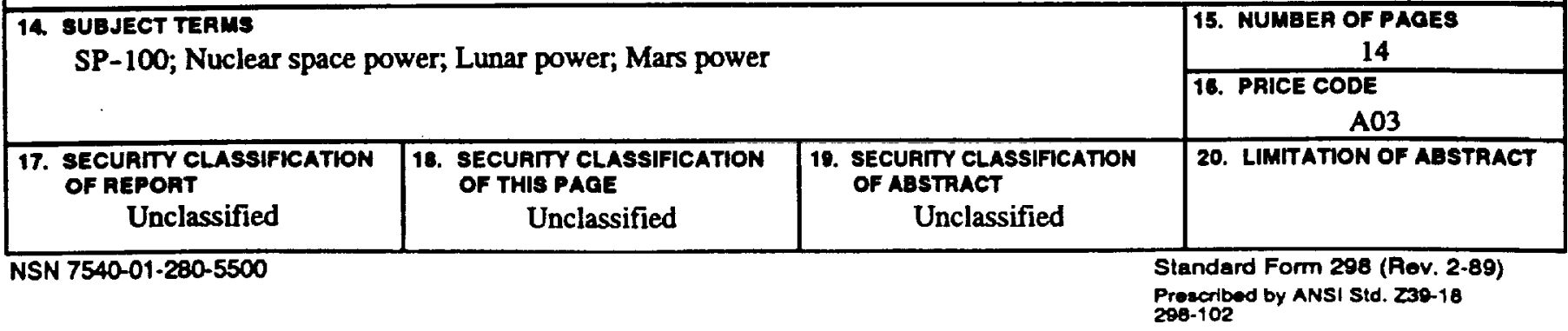


